\title{
Paweł Jagiełło
}

\author{
Uniwersytet Wrocławski
}

\section{Obietnice wyborcze składane przez polskie partie polityczne. Teoria i praktyka polityczna.}

Charakterystycznym elementem kampanii wyborczych, w większości państw demokratycznych, są obietnice, dzięki którym kandydaci, partie i inne komitety wyborcze, starają się trafić do wyborcy. Zupełnie naturalnym zjawiskiem jest więc ocenianie polityki zwycięskiej (i nie tylko) partii, pod kątem realizacji tych obietnic. Celem niniejszego artykułu, jest przedstawienie relacji, pomiędzy deklarowanym przez daną partię światopogladem, a składanymi doraźnie obietnicami wyborczymi oraz pomiędzy tymi obietnicami, a praktyką. Analizie poddano dwie partie: Prawo i Sprawiedliwość i Platformę Obywatelską Rzeczypospolitej Polskiej, gdyż te ugrupowania wygrały ostatnie trzy wybory do Sejmu i Senatu, a także Ruch Palikota, gdyż jest to nowa siła polityczna, której postulaty wzbudzają chyba największe kontrowersje. Rozważać będę program wyborczy PiS z 2005 roku, program PO z roku 2007, gdyż wtedy wspomniane partie doszły do władzy, a także program RP z roku 2011 - wtedy bowiem to ugrupowanie dostało się do Sejmu.

Prawo i Sprawiedliwość to partia, która powstała na bazie dawnego Porozumienia Centrum Pewną rolę odegrała także działalność Lecha Kaczyńskiego na stanowiskach prezesa NIK, Ministra Sprawiedliwości i Prokuratora Generalnego. Lech Kaczyński uzyskał wówczas dużą popularność. Partia została zarejestrowana 13 czerwca 2001 roku. Ugrupowanie prezentuje konserwatywne poglady w kwestiach moralnych - jest przeciwne rejestracji związów homoseksualnych, legalizacji aborcji na życzenie, eutanazji, czy legalizacji narkotyków miękkich. W statucie PiS (stan na rok 2009), możemy znaleźć następujące cele partii:

1. Umocnienie niepodległości Polski i jej pozycji międzynarodowej; 
2. Umocnienie siły i bezpieczeństwa Państwa Polskiego, a przede wszystkim jego zdolności do podejmowania przedsięwzięć inwestycyjnych i społecznych;

3. Umocnienie demokracji, praworządności i wolności obywatelskich;

4. Szerzenie postaw patriotycznych i wzmacnianie solidarności społecznej i narodowej;

5. Umacnianie roli rodziny jako podstawy społeczeństwa;

6. Szybki rozwój gospodarczy Polski, większy udział obywateli w korzystaniu z jego owoców, eliminacja różnic między miastem a wsią i pomiędzy regionami;

7. Rozwój kultury i nauki, powszechny dostęp do edukacji;

8. Zniesienie barier, ograniczających możliwości awansu społecznego, a także aktywności zawodowej, kulturalnej i naukowej.

Na podstawie celów statutowych, a także niezmiennie deklarowanych poglądów członków PiS na kwestie moralne, można stwierdzić, że partia ta odwołuje się do konserwatyzmu, a w kwestiach gospodarczych i społecznych do solidaryzmu i etatyzmu. Widzimy bowiem wysiłek w kierunku obrony wartości uznawanych przez konserwatyzm, jakimi sa państwo, naród, prawo, bezpieczeństwo, a także tradycyjne zasady moralne, wynikające na ogół z chrześcijaństwa. Z drugiej strony, mamy bezpośrednie odwołanie do solidaryzmu (wzmacnianie solidarności społecznej i narodowej), oraz dążenie do wzmocnienia zdolności inwestycyjnych państwa, co wskazuje na odwołanie do etatyzmu1. Jeśli chodzi o stałe cele PiS-u, należy wspomnieć o dążeniu do lustracji i dekomunizacji.

Przyjrzyjmy się teraz programowi Prawa i Sprawiedliwości z 2005 roku, który przyniósł tej partii zwycięstwo wyborcze. PiS szedł do tamtych wyborów z hasłem „IV Rzeczpospolita - Sprawiedliwość dla Wszystkich”. Program został podzielony na dwa zespoły działań. Pierwszy dotyczył naprawy państwa, drugi natomiast nowej polityki gospodarczej. Ze względu na ograniczenia czasowe, zajmę się tylko wybranymi zagadnieniami.

Polska miała stać się uczciwym i sprawnym państwem. Postulowano rozszerzenie lustracji - ujawnienie wszystkich agentów i funkcjonariuszy peerelowskich służb specjalnych, ujawnienie teczek osób sprawujących władzę. Planowano likwidację postkomunistycznych instytucji i przebudowę służb

\footnotetext{
1 Statut Prawa i Sprawiedliwości, s. 4.
} 
specjalnych. Planowana była również likwidacja uprzywilejowania peerelowskich funkcjonariuszy. Wśród innych planów, wspomnieć należy o urzeczywistnieniu odpowiedzialności dyscyplinarnej sędziów, reformie służby cywilnej, powołaniu Urzędu Antykorupcyjnego, reformach w resorcie spraw wewnętrznych i administracji, czy też nowej strategii informatyzacji państwa2.

Drugi rozdział, dotyczył bezpieczeństwa. Zapowiedziano wprowadzenie nowego Kodeksu Karnego, autorstwa Lecha Kaczyńskiego. Kary miały być bardziej dotkliwe, nieuchronne i sprawiedliwe. Wymienić można m.in. Wprowadzenie dłuższej kary pozbawienia wolności - do 25 lat, bezwzględne dożywocie, konfiskatę mienia pochodzącego z przestępstw, podwyższenie dolnych granic kar dla recydywistów. Ponadto postulowano rozszerzenie zakresu dozwolonej obrony koniecznej. Zapowiedziana została reforma struktur śledczych i zwiększenie efektywności działania sądów - z drugiej strony także ograniczenie immunitetów sędziego i prokuratora. Miała mieć miejsce reforma policji - odtąd policja miała się kierować zasadą braku tolerancji wobec drobniejszych przestępstw33.

Kolejny rozdział dotyczył polityki zagranicznej. Najważniejsza miało być ochrona suwerenności i strategiczny sojusz z USA. Polska powinna zajmować w UE silną pozycję i działać na rzecz dalszego rozszerzenia Unii na wschód, a także starać się o utrzymanie zasady jednomyślności, zasady solidarności oraz niezależności gospodarczej. NATO miało być traktowane jako podstawowa instytucja gwarantująca pokój w Europie. Polska miała stać liderem regionalnym i współpracować z państwami Europy Środkowej. Istotną kwestią miała być obrona interesów polskiej mniejszości poza granicami kraju4.

Rozdział czwarty dotyczył gospodarki. Postulowano m.in. uproszczenie systemu podatkowego - zredukowanie liczby stawek do dwóch (18\% i 32\%, docelowo 18\% i 28\%). Utrzymane miało zostać wspólne rozliczanie się małżonków. Oszczędności miał przynieść projekt „Tanie państwo”, który polegał na likwidacji wielu urzędów. Sprzeciwiano się wprowadzeniu waluty euro - miała być ona wprowadzona dopiero, gdy będzie to dla Polski korzystne. Obiecano rozbudowę sieci dróg ekspresowych i modernizację PKP. Jeśli chodzi o prywatyzację -

\footnotetext{
2 Prawo i Sprawiedliwość Program 2005. IV Rzeczpospolita - Sprawiedliwość dla Wszystkich, s. 14-23.

3 Ibidem, s. 24-37.

4 Ibidem, s. 38-53.
} 
postulowano pozostawienie w rękach państwa przedsiębiorstw o strategicznym znaczeniu i prywatyzację reszty ${ }^{5}$.

Kolejny rozdział dotyczył rodziny. PiS postulował w nim aktywną politykę prorodzinną państwa. Wymieniono chociażby program „Rodzina na swoim”. Rozróżniono budownictwo społeczne i budownictwo socjalne. Proponowano także ulgi podatkowe, uzależnione od liczby dzieci w rodzinie, oraz od dochodów. Ułatwione miało być funkcjonowanie firm rodzinnych. Wspomnieć należy również o zdecydowanym sprzeciwie wobec aborcji i eutanazji. Telewizja publiczna miała krzewić wartości sprzyjające rodzinie. Władze publiczne miały reagować zdecydowanie na naruszenie ładu moralnego ${ }^{6}$.

Szósty rozdział dotyczył zdrowia. Postulowano w nim powszechny i równy dostęp do służby zdrowia. NFZ miał zostać zlikwidowany, a służbę zdrowia miał finansować budżet państwa. Proponowano wprowadzenie koszyka gwarantowanych świadczeń medycznych, a także możliwości wykupienia dodatkowych ubezpieczeń komercyjnych?.

Kolejny rozdział dotyczył edukacji. Obiecywano dbanie o wysoki poziom szkolnictwa wyższego i utrzymanie bezpłatnych studiów. Jeśli chodzi o edukację, zwiększony miał być dodatek motywacyjny dla nauczycieli. Szkoła miała zapewniać opiekę medyczną i dożywianie, wprowadzony miał być nowy system finansowania stypendiów, ustalone miały być także ceny maksymalne podręczników. Prowadzona miała być polityka wyrównywania szans, a jak największa liczba uczniów miała być objęta maturą.

Ósmy rozdział programu wyborczego dotyczył kultury. Proponowano również stworzenie systemu mecenatu państwowego, ścisłą współpracę z twórcami, upowszechnianie twórczości i dostępu do kultury, a także ochronę mediów publicznych. Proponowano likwidację KRRiT. Media publiczne miały stać się niezależne od nacisków publicznych, miały realizować misję w zakresie kultury i edukacji. PiS był przeciwny prywatyzacji publicznych stacji radiowych i telewizji. Postulowano przyjęcie i egzekwowanie przepisów zabraniających emisji programów zawierających przemoc oraz treści demoralizujące. Polityka kulturalna miała być

5 Ibidem, s. 54-73.

6 Ibidem, s. 74-83.

7 Ibidem, s. 84-93.

8 Ibidem, s. 94-103. 
ukierunkowana na kształtowanie postaw patriotycznych i obywatelskich. Wspomniano o planach budowy Muzeum Wolności9.

Kolejny rozdział dotyczył polityki społecznej. Każdy Polak miał mieć podobne warunki startu życiowego. Wszyscy mieli korzystać z rozwoju gospodarczego. PiS proponował Polakom zawarcie „Nowej Umowy Społecznej”. Miała ona objąć takie sprawy jak: naprawa państwa, polityka prozatrudnieniowa, program mieszkaniowy, likwidacja cywilizacyjnej zapaści niektórych regionów, przywrócenie ochrony pracy, polityka prorodzinna, przebudowa systemów ochrony zdrowia i edukacji, polepszenie jakości życia Polaków, szczególnie słabszych grup społecznych. Postulowano wprowadzenie prorodzinnej ulgi podatkowej i wydłużenie urlopu macierzyńskiego10.

Rozdział dziesiąty dotyczył rolnictwa i obszarów wiejskich. W programie wspomniano o planach negocjowania większej ilości dopłat z UE, a także ułatwieniach w eksporcie produktów rolnych do UE i ochrony własnego rynku produktów rolnych. Wspierany miał być rozwój agroenergetyki. Usprawniony miał zostać proces sprzedaży i dzierżawy ziemi znajdującej się we władaniu Agencji Nieruchomości Rolnej, jednak możliwość kupna ziemi przez cudzoziemców miała być ograniczona11.

Ostatni rozdział programu dotyczył sportu. Sport uprawiany przez zwykłych ludzi miał przynieść zmniejszenie nakładów na służbę zdrowia. Sport masowy i wyczynowy miał być dotowany z wpływów z Totalizatora Sportowego i Polskiego Monopolu Loteryjnego. Kontrola nad finansami przeznaczonymi na sport miała być zwiększona, a kibice mieliby mieć wpływ na wybór zarządzających klubami i związkami sportowymi. Wprowadzone miały być zasady poszanowania prawa w sporcie i specjalne kary dla stadionowych chuliganów ${ }^{12}$.

Postarajmy się teraz przeanalizować relacje, pomiędzy zapisanymi w statucie Prawa i Sprawiedliwości celami oraz deklarowanymi niezmiennie pogląami, a przytoczonym programem wyborczym. Wydaje się, że na ogół są one ze sobą zgodne. Ambitny program poprawy bezpieczeństwa państwa, czyli chociażby bardziej restrykcyjne kary, większa sprawność sądów, prokuratury, czy policji, oraz rozszerzenie zakresu obrony koniecznej koresponduje z celami, takimi

\footnotetext{
9 Ibidem, s. 104-111.

10 Ibidem, s. 112-125.

11 Ibidem, s. 126-137.

12 Ibidem, s. 138-144.
} 
jak umocnienie bezpieczeństwa państwa, czy umocnienie praworządności. Z tym drugim celem, koresponduje również program budowy uczciwego sprawnego państwa, a w szczególności program antykorupcyjny. Natomiast rozdział dotyczący polityki zagranicznej, realizuje założenia celów, takich jak umacnianie niepodległości Polski i jej pozycji międzynarodowej, oraz umacnianie siły i bezpieczeństwa państwa. Głównym celem polityki kulturalnej, ma być propagowanie postaw patriotycznych i obywatelskich - koresponduje to z pierwszym z celów, wymienionych w punkcie czwartym - szerzenie postaw patriotycznych. W programie uwzględniony został również cel wymieniony zaraz po nim, czyli wzmacnianie solidarności społecznej i narodowej. Działania w tym kierunku zostały obszernie opisane w rozdziale dotyczacym polityki społecznej (głównie w zarysach „Nowej Umowy Społecznej”) oraz w rozdziałach na temat zdrowia i rodziny. Wspomniano również o nich w rozdziale omawiającym problemy gospodarki.

Zauważmy, że wszystkie cele zapisane w statucie zostały uwzględnione w omawianym programie wyborczym.

Warto podjąc także rozważania, na temat praktycznej realizacji obietnic wyborczych. Prawo i Sprawiedliwość skupiło się przede wszystkim na realizacji postulatów z rozdziału pierwszego. Udało się powołać Centralne Biuro Antykorupcyjne, podjęto pewne działania w zakresie likwidacji instytucji postkomunistycznych i przebudowy sił specjalnych - mowa tutaj o likwidacji WSI, przeprowadzonej w 2006 roku. Nie powiodła się natomiast likwidacja przywilejów funkcjonariuszy służb specjalnych PRL i rozszerzenie lustracji. Ustawa została skierowana do pierwszego czytania, ale nie uchwalono jej przed rozwiązaniem Sejmu V kadencji. Przyjęto jedynie część poprawek umożliwiających szybszy i powszechny dostęp do materiałów IPN, a także usprawniono postępowanie lustracyjne. Uchwalono ustawy o informatyzacji podmiotów realizujących działania publiczne oraz o służbie cywilnej. Znowelizowano Kodeks Karny, jednak zmiany nie były tak radykalne jak zapowiadano. Uchwalono ustawę o modernizacji Policji i innych służb. Zmieniono procedurę uzyskiwania zezwolenia na pociagnięcie do odpowiedzialności karnej sędziego. Pozostałych zmian nie udało się wprowadzić.

PiS realizował przewidziana w programie wyborczym politykę zagraniczna. Dążono do utrzymania zasady jednomyślności i solidarności. Starano się utrzymywać dobre stosunki z państwami Europy Środkowej oraz z Ukrainą. Uchwalono ustawę wprowadzającą tzw. Kartę Polaka. Konsekwentnie wspierano 
również Stany Zjednoczone, popierając projekt umiejscowienia w Polsce części instalacji amerykańskiej tarczy antyrakietowej. Jeśli chodzi o gospodarkę, udało się zredukować liczbę stawek podatkowych do dwóch, utrzymano także wspólne rozliczanie się małżonków. Nie udało się osiagną́ realnych oszczędności w administracji - liczba urzędników znowu wzrosła, choć nieznacznie. Waluty euro, jak zapowiadano, nie wprowadzono. Podpisano kontrakty na budowę kilku odcinków autostrad i dróg ekspresowych, jednak na pewno nie to miał na myśli wyborca, czytając w programie wyborczym o rozbudowie sieci dróg. Nie przeprowadzono istotnych działań w celu modernizacji PKP. Spełniono obietnicę wyborcza, w zakresie ograniczenia prywatyzacji strategicznych przedsiębiorstw.

W zakresie polityki prorodzinnej podwyższono dodatek z tytułu urodzenia dziecka. Uchwalono ustawę o dożywianiu dzieci w szkołach. Wprowadzono również dopłaty do kredytu mieszkaniowego nie zlikwidowano jednak NFZ. Nie zdążono też uchwalić ustawy wprowadzającej koszyk świadczeń gwarantowanych. Utrzymano bezpłatne studia wyższe. Nie udało się wprowadzić pozostałych zmian w zakresie polityki prorodzinnej, edukacji i zdrowia. Jeśli chodzi o politykę kulturalna, przede wszystkim nie zlikwidowano KRRiT, choć kilkakrotnie nowelizowano ustawę. Implementowano natomiast jedną z dyrektyw UE, dotyczącą prawa autorskiego. Nie zrealizowano planów budowy Muzeum Wolności. W zakresie polityki społecznej, nie udało się przede wszystkim zawrzeć zapowiadanej „Nowej Umowy Społecznej”. Powiodło się natomiast, o czym już wspominałem, wprowadzenie dopłat do kredytów mieszkaniowych. Uchwalono też ustawę przewidującą stopniowe wydłużanie urlopów macierzyńskich. W zakresie rolnictwa zmieniono ustawę - Agencji Restrukturyzacji i Modernizacji Rolnictwa wprowadzając możliwość udzielania przez tę agencję dopłat do roślin wykorzystywanych na cele energetyczne. Uchwalono też kilka innych ustaw porządkujących kwestie dopłat oraz szereg ustaw dotyczących poszczególnych rynków produktów rolnych. Uchwalono ustawę zmieniająca sposób przedłużenia umowy dzierżawy gruntu rolnego od Agencji Nieruchomości Rolnych. W zakresie sportu wprowadzono dożywotnie renty dla zawodników reprezentujących Polskę na Igrzyskach Olimpijskich. Uchwalono też ustawę o bezpieczeństwie imprez masowych.

Przejdźmy teraz do Platformy Obywatelskiej Rzeczypospolitej Polskiej. Partia ta powstała początkowo jako stowarzyszenie 24 stycznia 2001 roku, a została zarejestrowana jako partia polityczna 5 marca 2002. Powstała głównie ze środowisk Unii Wolności i części AWS. Założycielami byli Donald Tusk z UW, 
Maciej Płażyński z AWS i bezpartyjny Andrzej Olechowski, który w roku 2000, zajał drugie miejsce w wyborach prezydenckich. Partia deklaruje poglądy określane mianem konserwatywno-liberalnych i chrześcijańsko-demokratycznych. W Statucie Platformy Obywatelskiej Rzeczypospolitej Polskiej, nie mamy wypisanych tak konkretnych celów jak w Statucie PiS-u. Możemy znaleźć tam następujące cele:

1. Cywilizacyjny i gospodarczy rozwój Rzeczypospolitej jako demokratycznego państwa prawnego;

2. Udział w życiu publicznym Rzeczypospolitej Polskiej;

3. Wywieranie metodami demokratycznymi wpływu na działalność państwa;

4. Wysuwanie kandydatów na stanowiska w organach państwowych i samorządowych.

Tylko pierwszy ze statutowych celów można uznać za cel sensu stricte, do którego partia dąży, pozostałe to raczej sposób działania13. Platforma opowiada się w swoich programach wyborczych za umiarkowanym liberalizmem gospodarczym, postulując m.in. Wprowadzenie podatku liniowego, ograniczenie deficytu budżetowego i dokończenie prywatyzacji. W kwestiach ustrojowych, na czoło wysuwa się postulat wprowadzenia jednomandatowych okręgów wyborczych. Partia jest również pozytywnie nastawiona do przyjęcia przez Polskę waluty euro, opowiada się także za kontynuacją integracji z UE. PO jest umiarkowanie konserwatywna w sprawach moralnych - do tej pory partia opowiada się za utrzymaniem obowiązującego prawa w dziedzinie aborcji, czy eutanazji, trwaja prace nad wypracowaniem stanowiska w sprawie zwiazków partnerskich i in vitro.

Przewodnim hasłem programu wyborczego PO z 2007 roku było „Polska zasługuje na cud gospodarczy". Właśnie na gospodarkę był kładziony największy akcent.

Rozdział pierwszy mówił o państwie silnym, tanim i przyjaznym. Państwo miało być nowoczesne, zdolne do sprostania wyzwaniom XXI wieku. Państwo nie może być wyobcowane w UE. Postulowano zbudowanie nowej koncepcji suwerenności, adekwatnej do członkostwa w UE. Konieczne miało być działanie w duchu społeczeństwa obywatelskiego, odwoływanie się do interesu narodowego, ale też wzmocnienie tożsamości regionalnej i lokalnej. Państwo miało być lepiej zorganizowane, a administracja bardziej przyjazna i tańsza. Postulowano również umowę rządu z samorządem, dotycząca decentralizacji. Większe aglomeracje

${ }_{13}$ Statut Platformy Obywatelskiej Rzeczypospolitej Polskiej, s. 1-2. 
powinny tworzyć związi metropolitalne. Postulowano usprawnienie władzy ustawodawczej i procesu legislacyjnego. Działania te miałyby prowadzić do uproszczenia prawa. Najważniejsze stanowiska administracyjne, miały należeć do przedstawicieli Służby Cywilnej, a nie partyjnych działaczy. Postulowano kodyfikacje prawa wyborczego. Proponowano wprowadzenie jednomandatowych okręgów wyborczych, w wyborach samorządowych oraz systemu mieszanego w wyborach do Sejmu. Rola prokuratury miała być zmniejszona, konieczne miało być rozdzielenie funkcji Ministra Sprawiedliwości i Prokuratora Generalnego ${ }^{14}$.

Kolejny rozdział dotyczył dbania o wolność i bezpieczeństwo obywateli. Proponowano rozdzielenie MSWiA, na dwa ministerstwa, wzmocnienie kompetencji ministra spraw wewnętrznych i ustanowienie ponadpartyjnego „paktu antykorupcyjny"15.

Rozdział trzeci dotyczył własności i sprawiedliwości. Istotnym elementem wolności obywatela miała być wolność gospodarcza. Postulowane było upowszechnienie własności (mieszkań, domów, akcji, zwracanego mienia). Planowano likwidację instytucji wieczystego użytkowania, jako reliktu poprzedniego ustroju. Proponowano przekształcenie praw spółdzielczych w prawo własności oraz wprowadzenie zmian legislacyjnych, dzięki którym odszkodowanie za wywłaszczenie na cele publiczne miało się stać naprawdę godziwe, dzięki czemu inwestycje napotykałyby na mniej przeszkód. Proponowano wieloletni plan prywatyzacyjny, oddzielajacy prywatyzację od planowania budżetowego. Środki uzyskane w ten sposób miały być przeznaczone na naprawdę ważne cele. Zamiast państwowej własności w sektorze energetycznym postulowano zwiększenie uprawnień regulacyjnych państwa i stopniową prywatyzację oraz przeprowadzenie rzetelnej reprywatyzacji w naturze bądź za pomocą słusznej rekompensaty ${ }^{16}$.

W następnym rozdziale poruszono problemy finansów i gospodarki. Postulowano wprowadzenie zarządzania, zorientowanego na osiaganie zaplanowanych rezultatów. Chodzi o budżet zadaniowy - pieniądze nie na funkcjonowanie urzędu, tylko na realizację konkretnych zadań. Postulowano ograniczenie deficytu budżetowego. Istotnym elementem programu wyborczego było obniżenie podatków. Postulowano wprowadzenie podatku liniowego - 15\%

\footnotetext{
14 Program wyborczy Platformy Obywatelskiej 2007. Polska zasługuje na cud gospodarczy, Warszawa 2007, s. $10-16$.

15 Ibidem, s. 17-19.

16 Ibidem, s. 19-22.
} 
zamiast podatku dochodowego od osób fizycznych (PIT) i od osób prawnych (CIT), podatku od wynagrodzeń oraz podatku od działalności gospodarczej. Proponowano m.in. likwidację opodatkowania spadków. Jeśli chodzi o VAT - postulowano utrzymanie stawki, zredukowanej dla części towarów. Proponowano partnerstwo publiczno-prywatne dla lepszego wykorzystania funduszy strukturalnych i zwiększenia innowacyjności. Istotnym punktem tej części programu jest usuwanie barier biurokratycznych, hamujących rozwój przedsiębiorstw. Istotne miało być ułatwienie zarówno zakładania, jak i prowadzenia firmy oraz podjęcie działań na rzecz dywersyfikacji źródeł energii (z wykorzystaniem potencjału krajowego) . Nacisk miał być kładziony również na energię odnawialną ${ }^{17}$.

W rozdziale piątym przedstawiono pomysły na rozwiązania w dziedzinie ochrony zdrowia. NFZ miał zostać podzielony na kilka konkurujących ze soba funduszy publicznych. Proponowano określenie minimalnego zakresu świadczeń, wynikających z podstawowego ubezpieczenia. Wprowadzony miał być także system ubezpieczeń dodatkowych, prowadzonych przez fundusze publiczne i prywatne. Stawka powszechnego ubezpieczenia zdrowotnego, miała być naliczana na podstawie PIT. Wszystkie podmioty, udzielające usług medycznych w zakresie ubezpieczenia podstawowego, miały być traktowane tak samo18.

Kolejny rozdział dotyczył polityki społecznej. Jednym z celów miało być podniesienie wskaźnika dzietności. Postulowano wydłużenie urlopu macierzyńskiego i upowszechnienie urlopu wychowawczego. Planowano zapewnienie młodemu pokoleniu dostępu do mieszka i dostosowanie systemu edukacji do wymogów rynku pracy. Oznaczało to m.in. Wprowadzenie wcześniejszej nauki języka angielskiego i większy nacisk na zdobywanie umiejętności informatycznych. W planach było również stopniowe podwyższanie wieku emerytalnego - do 2025 zrównanie kobiet i mężczyzn (67 lat), oraz wprowadzenie emerytur pomostowych ${ }^{19}$.

W rozdziale siódmym poruszono kwestie sektora wiedzy. Postulowano wprowadzenie do sektora wiedzy mechanizmów rynkowych, spójnej podstawy programowej, od przedszkola, do szkoły średniej. Szkoła miała uczyć praktycznych umiejętności, zamiast wiedzy encyklopedycznej. Postulowano wprowadzenie obowiązku nauki, co najmniej jednego języka obcego, od pierwszej klasy szkoły

\footnotetext{
17 Ibidem, s. 23-34.

18 Ibidem, s. 34-40.

19 Ibidem, s. 40-50.
} 
podstawowej. Postulowano wprowadzenie bonu edukacyjnego. Innym planem było obniżenie wieku szkolnego do lat 6 . Jeśli chodzi o szkolnictwo wyższe, program studiów miał być dopasowany do wymogów rynku pracy. W planach było również zlokalizowanie Europejskiego Instytutu Technologicznego we Wrocławiu20.

Kolejny rozdział dotyczył obecności Polski w Europie i polityki regionalnej. Władze publiczne miały współpracować z partnerami społecznymi przy wyborze projektów. Wspierane z funduszy, miały być przede wszystkim: inwestycje w infrastrukturę komunikacyjna, umożliwienie dostępu do Internetu każdemu, rozbudowa lotnisk regionalnych, rozwój połączeń między nimi, promowanie przyjaznych środowisku środków transportu, rozwój kolei, dywersyfikacja źródeł energii, wspieranie innowacyjności gospodarki, stworzenie mechanizmów współpracy między uczelniami, władzami i podmiotami gospodarczymi, rewitalizacja i rozwój dużych miast, wspieranie budownictwa mieszkaniowego. PO postulowało wzmocnienia kadrowe i organizacyjne organów administracyjnych, odpowiedzialnych za zarządzanie funduszami europejskimi21.

Rozdział dziewiąty dotyczył polskiej wsi. Proponowano umowę społeczna, opartą na następujących założeniach: kompetentna polska polityka na rzecz wsi w UE, regionalizacja polityki rozwoju wsi, przebudowa instytucji wspierajacych rolnictwo, polityka żywnościowa, stymulująca kooperację i tworzenie więzi gospodarczych, wzmacnianie społeczeństwa obywatelskiego i prowadzenie mądrej polityki społecznej. Planowano działania na rzecz zwiększenia wysokości dopłat bezpośrednich do poziomu w starych krajach członkowskich. Planowano wprowadzenie spójnego systemu nadzoru jakości produkowanej żywności Inspekcja Weterynaryjna i Bezpieczeństwa Żywności. Postulowano zwiększenie roli sołtysa w życiu wsi oraz przyjęcie ustawy o funduszu sołeckim. KRUS miał zostać utrzymany, ale zreformowany22.

Kolejny rozdział podejmował problematykę mediów elektronicznych. Zamierzano wprowadzić zmiany prawne i organizacyjne, pozwalające na pełne wykorzystanie możliwości cyfryzacji. Chciano zlikwidować obecny i powołać nowy regulator rynku komunikacji elektronicznej - kompetencje KRRiTV oraz Urzędu Komunikacji Elektronicznej23.

\footnotetext{
20 Ibidem, s. 50-54.

21 Ibidem, s. 55-59.

22 Ibidem, s. 59-66.

23 Ibidem, s. 66-68.
} 
Jedenasty rozdział dotyczył kultury i dziedzictwa narodowego. Kultura miała łączyć tradycję z nowoczesnością. Polityka kulturalna miała zarówno pielęgnować dziedzictwo kulturowe, jak i wspierać twórców i sztukę współczesna, dbać o równy dostęp do kultury, umacnianie wielokulturowości i dialog międzykulturowy. Planowano wykorzystanie funduszy unijnych i innych funduszy pozabudżetowych. Z funduszy unijnych zamierzano finansować m.in. rozbudowę infrastruktury kultury oraz ochronę dziedzictwa kulturowego. Innym źródłem byłby tzw. „procent na kulturę” - podmioty budujące, rozbudowujące lub remontujące obiekty publiczne musiałyby przeznaczać $1 \%$ na sztukę współczesną24.

Rozdział kolejny, zatytułowany był „Silna i bezpieczna Polska w Unii Europejskiej". Zakładano w nim umocnienie pozycji Polski w strukturach NATO i UE. Konieczne miało być maksymalne wykorzystanie funduszy unijnych. Polska miała dążyć do stania się jednym z liderów Unii. Postulowano uczynienie zasady solidarności podstawą wewnętrznej spoistości UE. Popierano „Strategię Wzrostu i Zatrudnienia", a szczególnie zapisy o otwieraniu rynków, deregulacji oraz wsparciu małej i średniej przedsiębiorczości, a także postulowano walkę o otwarcie rynków pracy dla Polaków. Planowano wsparcie dla programów wymiany studentów, uczniów i nauczycieli. Polityka wobec Rosji, miała być oparta na chłodnej kalkulacji i wymagająca wyzbycia się emocji. Celem miały być stosunki dobrosąsiedzkie. Istotnym partnerem Polski miała być Ukraina. Polska miała wspierać przemiany demokratyczne w tym kraju i dążenia do integracji z Zachodem. W temacie bezpieczeństwa, postulowano $z$ jednej strony własny wkład we współpracę międzynarodowa, a z drugiej strony wzmacnianie sił zbrojnych. Miara naszych aspiracji miały być możliwości gospodarki i państwa. Polityka bezpieczeństwa miała być kierowana przez profesjonalistów, a nie przez funkcjonariuszy partyjnych. Planowano także transformację Sił Zbrojnych RP - profesjonalizację (likwidacja poboru, wprowadzenie ochotniczych sił rezerwowych) i modernizację. Nasz udział w misjach zagranicznych miał być adekwatny do naszych możliwości i odpowiadać interesom Polski. Nieprzedłużanie misji w Iraku i zmiana zaangażowania w Afganistanie na cywilne lub cywilno-wojskowe25.

Oceńmy teraz zgodność przytoczonego programu, z deklarowanymi na ogół przez Platformę Obywatelską poglądami. Liberalna polityka gospodarcza zapowiedź wprowadzenia podatku liniowego 15\%, a także zapowiedź usunięcia

\footnotetext{
24 Ibidem, s. 69-74.

25 Ibidem, s. 74-86.
} 
biurokratycznych barier, przeszkadzających w zakładaniu i prowadzeniu firmy wskazuje na realizację celu pierwszego, jakim było dążenie do cywilizacyjnego i gospodarczego rozwoju Polski. Podkreśla to również liberalny charakter ugrupowania. Z kolei do chadeckich poglądów, do jakich zalicza się solidaryzm, nawiązuje polityka prorodzinna, pozostawienie KRUS, czy zwiększenie środków na zwalczanie bezrobocia. Jeżeli chodzi o poglądy konserwatywne, trudno znaleźć w programie bezpośrednie do nich odwołanie. Brak jednak postulatów naruszających istniejący kompromis w kwestiach światopoglądowych - wskazuje to na typowe dla PO łagodne poglądy zachowawcze.

Polityka zagraniczna PO jest rzeczywiście bardziej pro-unijna niż polityka PiS. Podpisano „Traktat Lizboński”, a podczas następnej kadencji także „Pakt Fiskalny".

Uchwalono Kodeks Wyborczy. Nie udało się wprowadzić systemu mieszanego w wyborach do Sejmu. Rozłączono funkcje Ministra Sprawiedliwości i Prokuratora Generalnego. Nie wprowadzono także jednomandatowych okręgów wyborczych w wyborach samorządowych, za to wprowadzono taki system w wyborach do Senatu. MSWiA wedle zapowiedzi, zostało rozdzielone na dwa ministerstwa. W zakresie własności, nie zlikwidowano instytucji użytkowania wieczystego. Znowelizowano ustawę o spółdzielczości, w zakresie możliwości przekształcenia spółdzielczego prawa własności, na prawo własności. Inwestycje w dalszym ciagu napotykaja na problemy, w postaci osób twierdzących, że proponowano im za niskie odszkodowanie. Cały czas prowadzona jest prywatyzacja, w tym również przedsiębiorstw energetycznych (np. Zespół Elektrowni Pątnów-Adamów-Konin). Rzetelna reprywatyzacja wciąż nie została przeprowadzona, choć mają miejsce pewne postępy. Jeśli chodzi o finanse, wprowadzono budżet zadaniowy - poszczególne urzędy dostają pieniądze nie na swoje wydatki, tylko na wykonanie konkretnych zadań. Nie zlikwidowano deficytu budżetowego. Podczas rządów PO, dług publiczny poważnie wzrósł. Nie wprowadzono podatku liniowego, nie obniżono również podatków. Nie przekształcono też podatków PIT i CIT w podatek od wynagrodzeń i podatek od działalności gospodarczej. Nie zlikwidowano opodatkowania spadków. Podwyższono podatek VAT na część towarów (wcześniej stawki VAT na nie były zredukowane). Uchwalono ustawę o likwidacji barier administracyjnych dla obywateli i przedsiębiorców - efekty nie są jednak zbyt widoczne. W systemie partnerstwa publiczno-prywatnego wybudowano część autostrad. Uchwalono 
ustawę o partnerstwie publiczno-prywatnym. Trwa proces informatyzacji ksiag wieczystych - tzw. "migracja ksiag wieczystych”. Nie zrobiono wiele w celu dywersyfikacji źródeł energii - ciagle zdecydowana większość energii elektrycznej wytwarzana jest przez elektrownie cieplne, opalane węglem. Podczas trwania drugiej „kadencji” rządów PO, uchwalona została ustawa, o odnawialnych źródłach energii, wychodząca naprzeciw zobowiazzaniom Polski wobec UE. Zakłada on większe wsparcie dla wytwarzania energii z odnawialnych źródeł. W zakresie służby zdrowia nie podzielono NFZ na konkurujące ze sobą fundusze. Wprowadzono natomiast koszyk świadczeń gwarantowanych. W zakresie polityki społecznej, kontynuowany był program „Rodzina na swoim”, stworzono również nowy „Mieszkanie dla młodych”. Podwyższony został również wiek emerytalny - tu rząd wybiegł w przyszłość, realizując to, co zamierzał osiagnąć w 2025 roku. W szkołach rzeczywiście widać większy nacisk na naukę języka angielskiego i umiejętności informatycznych. Jeśli chodzi o edukację, przeprowadzono poważną reformę programową, która wzbudziła liczne kontrowersje. Nie powiodło się zlokalizowanie Europejskiego Instytutu Technologicznego we Wrocławiu. Nie są widoczne również mechanizmy rynkowe w sektorze wiedzy. Nie wprowadzono także bonu edukacyjnego. Uchwalono ustawę o rozpoczęciu obowiązku szkolnego w wieku sześciu lat.

Jeśli chodzi o obecność Polski w Europie i politykę regionalna, wiele inwestycji jest wspieranych z funduszy unijnych. Sa to inwestycje w infrastrukturę komunikacyjna, promowanie przyjaznych środowisku, środków transportu, rozwój kolei, czy rewitalizacja i rozwój dużych miast. Organy administracyjne zostały niewatpliwie wzmocnione kadrowo, za rządów PO przybyło wielu urzędników. Planowana „umowa społeczna” w sprawie polskiej wsi nie została zawarta. Dopłaty bezpośrednie dla rolników są dalej realizowane, wprowadzono znów szereg aktów prawnych regulujących tą kwestię. Nie powołano Inspekcji Weterynaryjnej i Bezpieczeństwa Żywności. W dziedzinie mediów elektronicznych rozpoczęto proces cyfryzacji. Nie zlikwidowano KRRiT, więc także nie powołano nowego regulatora mediów elektronicznych. W dziedzinie kultury, nie wprowadzono zasady „1\% na kulturę". Wykorzystywano natomiast dotacje unijne, na rozbudowę infrastruktury kultury i ochronę dziedzictwa narodowego. W temacie polityki zagranicznej, Polska, za rządów PO, objęła kurs zdecydowanie pro-europejski. Natomiast ewidentnie rząd PO nie budował silnej pozycji Polski w UE. Przyznać należy, że fundusze unijne były wykorzystywane do wsparcia wielu ważnych 
przedsięwzięć, ale w wielu przypadkach dotacje były obwarowane nonsensownymi warunkami. Udało się otworzyć dla Polaków wiele rynków pracy. Jeśli chodzi o politykę wobec Rosji, rząd PO nie dbał o utrzymywanie stosunków partnerskich. Przed efektami niekorzystnej umowy w sprawie dostaw gazu z Rosją, która wiazała nas na wiele lat, uratowała nas dopiero Komisja Europejska, dzięki czemu umowa wiąże nas chociaż na krótszy okres.

Jeśli chodzi o obronność, zlikwidowano pobór i tym samym, zrealizowano obietnice profesjonalizacji Sił Zbrojnych RP. Jednak powołanie formacji rezerwowej - Narodowych Sił Rezerwowych nie powiodło się. W rezultacie siły zbrojne licza obecnie około 90 tys. żołnierzy. Cały czas postępuje do przodu proces modernizacji armii, jednak w dalszym ciagu posiada ona zbyt małe ilości sprzętu (samolotów, czołgów), a znaczna jego część wciąż jest przestarzała. Nie zrealizowano postulatu o przekształceniu misji w Afganistanie w misję cywilną lub cywilno-wojskową - dalej ma ona charakter stricte militarny.

Kolejna partia poddana analizie to Ruch Palikota. Partia została założona 1 czerwca 2011, gdyż założonej 22 października 2010 roku partii, groziło wykreślenie z ewidencji. Wcześniej, 20 sierpnia, Janusz Palikot złożył wniosek o rejestrację stowarzyszenia Ruch Poparcia Palikota. Zarówno stowarzyszenie, jak i partia, powstały na gruncie popularności uzyskanej przez samego Janusza Palikota, wcześniej posła PO (złożył rezygnację z członkostwa w klubie parlamentarnym PO 6 października 2010, a w styczniu 2011 złożył mandat poselski). W skład partii weszli byli członkowie PO, SLD i Socjaldemokracji Polskiej, a także ludzie nie związani wcześniej z polityką, w tym wywodzący się ze środowisk LGBT. Partia uzyskała również poparcie środowisk feministycznych. W statucie Ruchu Palikota możemy znaleźć następujące cele:

1. Podejmowanie działań służących przestrzeganiu zasad demokratycznego państwa prawa, transparentności w życiu publicznym, społecznej kontroli nad instytucjami zaufania publicznego oraz przeciwdziałania patologiom życia publicznego i społecznego;

2. Obrona wolności: równego statusu kobiet i mężczyzn w różnych dziedzinach życia, wolności sumienia i wyznania, wolności światopoglądowej, świeckości państwa, poszanowania odrębności etnicznych, narodowych, kulturowych i seksualnych;

3. Inspirowanie i wspieranie inicjatyw i akcji obywatelskich, zmierzajacych do wzrostu zaangażowania polskiego społeczeństwa w działania na rzecz 
rozwoju świadomości obywatelskiej oraz rozwoju kulturalnego i gospodarczego Rzeczypospolitej Polskiej.

4. Dbanie o swobodę w kształtowaniu własnego życia;

5. Prowadzenie polityki krajowej i międzynarodowej, mającej na celu realizację wartości konstytucyjnych Rzeczypospolitej Polskiej i statutowych zasad Ruchu Palikota;

Z przytoczonych celów wynika przede wszystkim, odwołanie do liberalizmu w sferze moralnej. Ruch Palikota cechuje również antyklerykalizm oraz mieszanka liberalizmu i socjalizmu w sferze gospodarczej. Partia walczy między innymi o realny rozdział Kościoła od państwa, równość rzeczywistą płci czy wprowadzenie związków partnerskich²6.

Program Ruchu Palikota „Nowoczesna Polska”, z którym wspomniana partia startowała w ostatnich wyborach do Sejmu zakładał między innymi.

Zagadnienie pierwsze to rozdział kościoła od państwa. Przede wszystkim partia przeciwna była finansowaniu Kościoła z budżetu. Proponowano zastosowanie modelu niemieckiego - obywatele decydują sami, ile pieniędzy z ich podatków dostaje ich kościół. Ponadto postulowano wycofanie lekcji religii ze szkół i powrót do salek katechetycznych. Oczywiście katecheci nie mieli być finansowani przez państwo (podobnie jak zresztą kapelani). Ponadto żądano uchylenia decyzji Komisji Majątkowej, oddającej mienie kościelne znacjonalizowane za czasów Polski Ludowej. Planowano również wprowadzenie zakazu pokazywania się osób duchownych w strojach o symbolice religijnej na oficjalnych uroczystościach ${ }^{27}$.

Druga część programu dotyczyła kwestii światopoglądowych. Przede wszystkim postulowano wprowadzenie instytucji związków partnerskich zarówno dla osób hetero- jak i homoseksualnych, pozostających co najmniej pięć lat w stałym związku. Miałyby one podatkowe i majątkowe prawa analogiczne do małżeństw. Pary homoseksualne nie miałyby jednak prawa do adopcji dzieci. Proponowano również legalizację narkotyków miękkich i liberalizację ustawy aborcyjnej - decyzję o aborcji miała podejmować kobieta. Postulowano także finansowanie zapłodnienia in vitro z budżetu państwa - liczba zarodków miała być ograniczona do niezbędnego minimum. Uważano za konieczne również ustawowe zagwarantowanie równych pensji dla mężczyzn i kobiet. Proponowano także

\footnotetext{
${ }^{26}$ Statut Ruchu Palikota, s. 2.

27 Program wyborczy Ruchu Palikota. Nowoczesna Polska, Katowice 2011, s. 6-8.
} 
wprowadzenie finansowania środków antykoncepcyjnych przez państwo oraz finansowanie dostępu do Internetu z budżetu państwa28.

Trzecia część programu dotyczyła walki z biurokracją. Postulowano przede wszystkim wprowadzenie zasady milczącej zgody - jeżeli w ciagu 60 dni urzędnik nie wyda decyzji, przyjmuje się, że jest ona pozytywna dla obywatela. Następnie proponowano wprowadzenie oświadczeń zamiast zaświadczeń ostatnie natomiast miałyby krążyć między urzędami bez pośrednictwa obywatela. Uważano również, że dokumenty urzędowe powinny być jawne. Proponowano także wprowadzenie w parlamencie komisji stałej, do walki z biurokracją. Ponadto urzędnicy mieli być odpowiedzialni za wydane decyzje29.

Część kolejna dotyczyła naprawy polityki. Postulowano likwidację Senatu i zmniejszenie liczby posłów do 360 . Ponadto mieli być oni wybierani w systemie mieszanym - 50\% w systemie partyjnym, a reszta w okręgach jednomandatowych. Proponowano wprowadzenie kadencyjności funkcji politycznych w tym partyjnych maksymalnie dwie kadencje. Partie byłyby finansowane z puli 2,5\% od podatku zalicza się do tej puli również wspomniane ewentualne darowizny na kościół i organizacje pozarządowe ${ }^{30}$.

W piątej części programu poruszono kwestie gospodarcze. Postulowano wprowadzenie podatku liniowego „3 razy 18\%” (PIT, CIT i VAT). Deficyt budżetowy miałby być obniżony o połowę w ciagu dwóch lat. Ministerstwo Gospodarki miało być zmienione na Ministerstwo Przedsiębiorczości - proponowano sprzedaż niewielkich pakietów Skarbu Państwa w różnych przedsiębiorstwach i przekazanie reszty uprawnień kontrolnych, Agencji Rozwoju Przemysłu. Ministerstwo miałoby się natomiast zajmować promowaniem przedsiębiorczości. Powinno zając się także promocją polskiej gospodarki. Postulowano także połączenie KRUS i ZUS. Odmienne stawki dla rolników miały być jednak utrzymane. Zmianą miało być wprowadzenie nadzoru korporacyjny (na wzór spółek giełdowych). Planowano wydłużenie wieku emerytalnego poprzez wzrost świadczeń za dłuższą pracę. Likwidacji miały też ulec przywileje mundurowych. Ponadto postulowano zmiany w ustawach: 0 zamówieniach publicznych, 0 planie zagospodarowania przestrzennego, o prawie budowlanym, 0 podpisie elektronicznym,

\footnotetext{
28 Ibidem, s. 9-12.

29 Ibidem, s. 13-17.

30 Ibidem, s. 18-21.
} 
o rachunkowości, o kosztach reklamy i reprezentacji, o VAT, o wykonywaniu różnych zawodów (w tym prawniczych) ${ }^{31}$.

Ostatni punkt programu dotyczył wojska i kultury. Postulowano zmniejszenie wydatków na armię z 2\% PKB na 1\%, a zaoszczędzone pieniądze miały być przeznaczone na dofinansowanie kultury. Polska miałaby również nie uczestniczyć w żadnych misjach zagranicznych oraz wyzbyć się w polityce zagranicznej wszelkich elementów militarnych. Jeśli chodzi o obronę kraju to Polska miała się skupić na funkcjach logistycznych i pomocy ludności na wypadek wojny32.

Przedstawiony program Ruchu Palikota jest zgodny z celami partii. Nie można jednak stwierdzić o zgodności z deklarowanymi poglądami. W przeszłości RP postulował rozszerzenie opieki socjalnej - zwiększenie liczby przedszkoli (w omawianym programie zostało to wspomniane tylko raz przy okazji postulatu likwidacji funduszu kościelnego. Omawiany program prezentuje na ogół liberalne spojrzenie na gospodarkę - elementami socjalnymi są jedynie postulaty darmowej antykoncepcji, zabiegów in vitro i Internetu. Partia przeżywa więc swoiste „wahnięcia”. Może mieć to dwa źródła - albo partia nie ma jeszcze ugruntowanych poglądów na sprawy gospodarcze i społeczne, albo można ją określić jako typową populistyczna partię protestu, dostosowujaca swój program do aktualnych tendencji. Wydaje się jednak, że właściwie wszystkie główne polskie partie, noszą znamiona partii populistycznych - zarówno więc Jarosław Kaczyński z PiS, rezygnujący nagle z nazywania SLD „postkomuna” w celu zagarnięcia elektoratu tej partii w drugiej turze wyborów prezydenckich w 2010 roku, PO gdy rząd zorganizowała akcję przeciwko sklepom z dopalaczami, typowo „na pokaz”, PSL dopasowujący swój program do niemal każdej partii, w celu wejścia z nią w koalicję, czy SLD prowadzący politykę prokościelną w okresie sprawowania władzy mimo typowo lewicowych poglądów.

Porównanie obietnic wyborczych Ruchu Palikota z praktyczną działalnością polityczna, będzie zasadniczo odmienne niż w przypadku PO czy PiS ponieważ RP jest jedną z partii opozycyjnych, w związku z czym brać będziemy pod uwagę jedynie projekty ustaw i postawę posłów tej partii. Ruch Palikota wzniósł projekt ustawy o zmianie ustawy Ordynacja Podatkowa. Projekt ustawy ma na celu wprowadzenie mechanizmu, służącego ujawnianiu zakamuflowanych działań, mających na celu utrudnienie ustalenia przedmiotu opodatkowania - Rejestru

\footnotetext{
31 Ibidem, s. 22-26.

32 Ibidem, s. 27-28.
} 
Operacji Gospodarczych. Ustawa mogłaby się sprawdzić, jako narzędzie pozwalające na lepszą ściagalność podatków. Inny projekt dotyczył nadzoru publicznego nad stosowaniem cen transakcyjnych - celem ustawy byłoby przeciwdziałanie wywożeniu kapitału za granicę, w celu uniknięciu opodatkowania. Wniesiono także projekt ustawy o zmianie ustawy o podatku dochodowym od osób fizycznych oraz ustawy o podatku dochodowym od osób prawnych. Nie poruszono jednak tam kwestii podatku liniowego, a znowu kwestię tzw. „szkodliwej konkurencji podatkowej". Inny projekt - ustawa o zmianie ustawy o mniejszościach narodowych i etnicznych oraz o języku regionalnym, a także niektórych innych ustaw zakładał między innymi uznanie dialektu śląskiego za język regionalny. Wniesiono też projekt ustawy o świadomym rodzicielstwie liberalizujący ustawę antyaborcyjną oraz zakładający refundację antykoncepcji. Inny projekt zakładał wprowadzenie instytucji związku partnerskiego ( został wniesiony wspólnie z posłami SLD). Przytoczone projekty dwóch ustaw, regulujących kwestie światopoglaqdowe i jednej, postulującej większe uprawnienia mniejszości etnicznej, wpisują się w program i statut Ruchu Palikota. Natomiast trzy ustawy poruszające kwestie podatkowe zdają się odbiegać od liberalnego programu gospodarczego, z kolei moga jednak posłużyć planowanej likwidacji deficytu budżetowego. Jeśli chodzi o politykę antyklerykalną wspomnieć należy przede wszystkim o żądaniu usunięcia krzyża z sali obrad Sejmu.

Podsumowując podjęte rozważania, należy stwierdzić, iż obie omawiane partie rządzące spełniły jedynie część obietnic. Należy zwrócić jednak uwagę, na nie spełnienie dwóch postulatów - nieuchwalenie podatku liniowego przez PO oraz nieuchwalenie tzw. „Ustawy Dezubekizacyjnej” przez PiS. Postulat wprowadzenia podatku liniowego był swego rodzaju osią liberalnego programu wyborczego PO. Bardzo wiele osób do głosowania na tą partię przekonał właśnie ten postulat. Przez niezrealizowanie tego punktu programu PO niejako odeszło od liberalnych elementów programu gospodarczego. PiS nie zrealizował natomiast istotnych elementów programu, jak zmiany ustawy lustracyjnej oraz obniżenie emerytur członkom dawnych służb. Tak więc obie partie poważnie zawiodły duże grupy swoich wyborców. 